Marquette University

e-Publications@Marquette

Biological Sciences Faculty Research and

Publications

Biological Sciences, Department of

10-1997

\title{
Expression of Smooth Muscle Myosin Heavy Chains and Unloaded Shortening in Single Smooth Muscle Cells
}

Daniel P. Meer

Marquette University

Thomas Eddinger

Marquette University, thomas.eddinger@marquette.edu

Follow this and additional works at: https://epublications.marquette.edu/bio_fac

Part of the Biology Commons

\section{Recommended Citation}

Meer, Daniel P. and Eddinger, Thomas, "Expression of Smooth Muscle Myosin Heavy Chains and Unloaded Shortening in Single Smooth Muscle Cells" (1997). Biological Sciences Faculty Research and

Publications. 596.

https://epublications.marquette.edu/bio_fac/596 
Marquette University

\section{e-Publications@Marquette}

\section{Biology Faculty Research and Publications/College of Arts and Sciences}

This paper is NOT THE PUBLISHED VERSION; but the author's final, peer-reviewed manuscript. The published version may be accessed by following the link in the citation below.

American Journal of Physiology: Cell Physiology, Vol. 273, No. 4 (1997): C1259-C1266. DOl. This article is (C) American Physiological Society and permission has been granted for this version to appear in ePublications@Marquette. American Physiological Society does not grant permission for this article to be further copied/distributed or hosted elsewhere without the express permission from American Physiological Society.

\section{Contents}

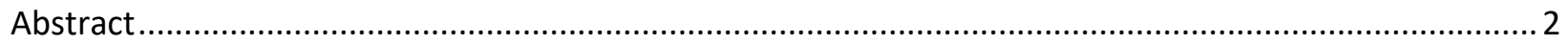

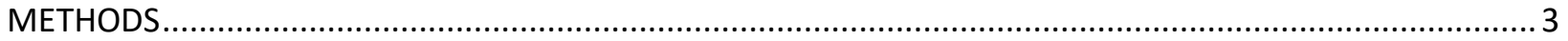

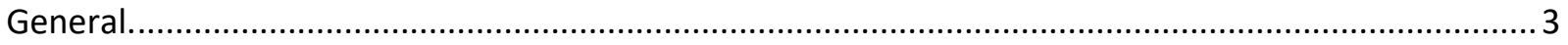

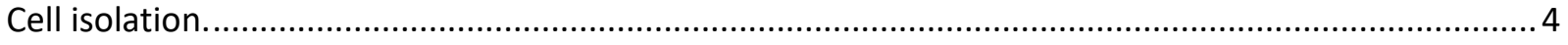

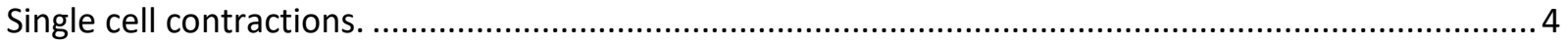

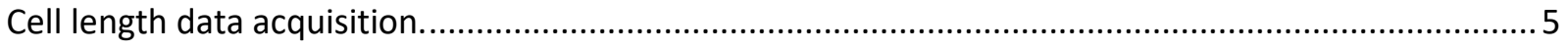

Untethered velocity measurements from single SMCs. ..........................................................

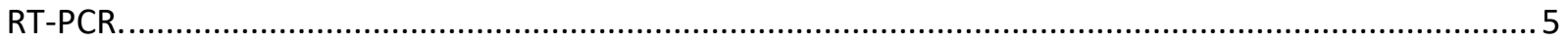

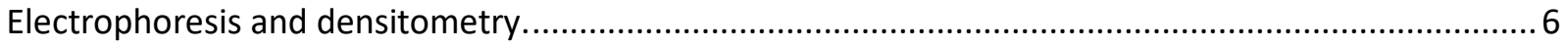

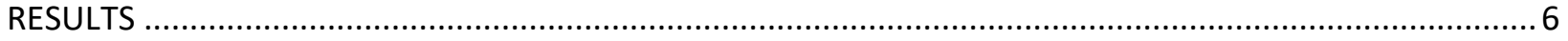

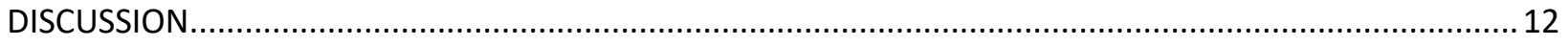

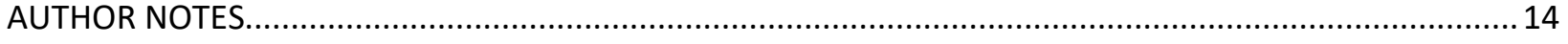

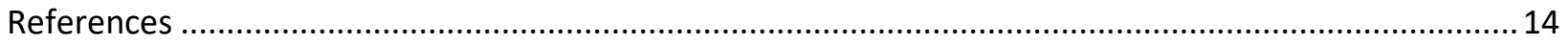




\title{
Expression of smooth muscle myosin heavy chains and unloaded shortening in single smooth muscle cells
}

\author{
Daniel P. Meer \\ Department of Biology, Marquette University, Milwaukee, WI \\ Thomas J. Eddinger \\ Department of Biology, Marquette University, Milwaukee, WI
}

\begin{abstract}
The functional significance of the variable expression of the smooth muscle myosin heavy chain (SM-MHC) tail isoforms, SM1 and SM2, was examined at the mRNA level (which correlates with the protein level) in individual permeabilized rabbit arterial smooth muscle cells (SMCs). The length of untethered single permeabilized SMCs was monitored during unloaded shortening in response to increased $\mathrm{Ca}^{2+}(\mathrm{pCa}$ 6.0), histamine $(1 \mu \mathrm{M})$, and phenylephrine $(1 \mu \mathrm{M})$. Subsequent to contraction, the relative expression of SM1 and SM2 mRNAs from the same individual SMCs was determined by reverse transcription-polymerase chain reaction amplification and densitometric analysis. Correlational analyses between the SM2-to-SM1 ratio and unloaded shortening in saponin- and $\alpha$-toxin-permeabilized SMCs $(n=28)$ reveal no significant relationship between the SM-MHC tail isoform ratio and unloaded shortening velocity. The best correlations between SM2/SM1 and the contraction characteristics of untethered vascular SMCs were with the minimum length attained following contraction ( $n=20$ and $r=0.72$ for $\alpha$ toxin, $n=8 \mathrm{and} r=0.78$ for saponin). These results suggest that the primary effect of variable expression of the SM1 and SM2 SM-MHC tail isoforms is on the cell final length and not on shortening velocity.
\end{abstract}

The first pair of mammalian smooth muscle myosin heavy chain (SM-MHC) isoforms, identified by differential mobility using polyacrylamide gel electrophoresis, was named SM1 and SM2. $\underline{29}$ The difference between SM1 and SM2 SM-MHC isoforms has been localized to the $3^{\prime}$ nonhelical tail region of the myosin molecule. . $^{27}$ It has been reported that one of the SM-MHC isoforms (SM1) has a 3' nonhelical tail similar to nonmuscle, embryonic, and invertebrate myosins, whereas the other (SM2) exhibits a truncated tail. $2,27,30,40$ The $3^{\prime}$ terminus of the MHC rod domain is critical to the nucleation process in myosin filament formation. 615 , $32 \mathrm{MHC}$ isoforms that exhibit nonhelical $3^{\prime}$ tails have been shown to have one or more conserved phosphorylatable serine residue(s) in this region. $\frac{18,19}{19}, 26$ The phosphorylation state of the $3^{\prime}$ tail site(s) has also been shown to influence filament formation and length. ${ }^{6 a, 17-19,21-23}$ The relative 
influence of the unphosphorylated SM1 nonhelical tail or the absence of nonhelical tail in SM2 on myosin filament assembly is not known.

Attempts to define the unique physiological functions for the SM-MHC $3^{\prime}$ tail isoforms, SM1 and SM2, have generated conflicting results. Mechanical studies performed on multicellular smooth muscle samples from various tissues under a variety of conditions have shown that SM1 levels correlate with small increases in the maximal velocity of muscle shortening $\left(V_{\max }\right), \underline{14}, \underline{35}$ decreases in force per unit weight,, 9 increases in $\mathrm{Ca}^{2+}$ sensitivity, and a decrease in unloaded shortening velocity. $\underline{5}$ Morano et al. $\underline{25}$ have reported a lack of correlation between the expression of either SM-MHC isoform, SM1 or SM2, and $V_{\max }$ in the same tissue used by Sparrow et al. .35 and Hewett et al. ${ }^{14}$ In vitro studies of molecular myosins have described hydrolytic and mechanical differences between the $\alpha$ - and $\beta$-cardiac MHC isoforms. $\frac{36}{}$ However, SM1 and SM2 are indistinguishable from one another with respect to their ability to move actin filaments using the in vitro motility assay. $\underline{20}$ Clearly, the relationship between the contractile properties of smooth muscles and their SM-MHC complement has not been determined.

One possible explanation for the discrepancy in these results is the fact that these mechanical studies were performed on tissue strips or purified proteins that were then assayed outside of their native three-dimensional organization. Several studies have reported differential expression of $\mathrm{MHC}$ isoforms among cells within the same smooth muscle tissue. $\underline{10}, \underline{12}, \underline{24}$ The averaging effect of studying a heterogeneous population, such as this, may mask the contribution of individual smooth muscle cells (SMCS) with unique SM-MHC isoform expression levels. To more directly address the possible unique physiological properties of the SM-MHC isoforms, we examined the correlation between the relative expression of SM1 and SM2 and the contractile properties of isolated SMCs. The experimental design avoids two of the potential pitfalls of previous studies. First, by making both the unloaded shortening and reverse transcription-polymerase chain reaction (RT-PCR) measurements in the same single SMC, one avoids problems of cellular heterogeneity and averaging. Second, with the use of an intact three-dimensional cell, intermolecular interactions that may be of significance are more likely to remain intact. The results of this study suggest that SM-MHC expression does not affect the unloaded shortening of isolated individual SMCs. Significant correlations between SM-MHC expression and minimum cell length were detected in this study. One possible explanation for this relationship between minimum length and isoform expression is that the SM1 and SM2 isoforms differentially affect myosin filament length and thus alter the range of shortening possible in these cells.

\section{METHODS}

\section{General.}

New Zealand White rabbits were killed by $\mathrm{CO}_{2}$ asphyxiation. Vascular tissues (aorta, carotid) were removed, cleaned of blood, adipose, and loose connective tissue, and stored in physiological salt solution [PSS; in $\mathrm{mM}: 140 \mathrm{NaCl}, 4.7 \mathrm{KCl}, 1.2 \mathrm{Na}_{2} \mathrm{HPO}_{4}, 1.2 \mathrm{MgSO}_{4}, 1.6 \mathrm{CaCl}_{2}$, 5.6 glucose, 0.02 EDTA, and 2.0 3-( $N$-morpholino)propanesulfonic acid (MOPS), pH 7.4] at $4{ }^{\circ} \mathrm{C}$ until processed. 
Cell isolation.

Individual cells were isolated from carotid or aortic arteries with methods modified from Driska and Porter (ㄱ). Briefly, the vessel is bisected longitudinally and incubated in $\mathrm{Ca}^{2+}$-free PSS (in $\mathrm{mM}: 140 \mathrm{NaCl}, 4.7 \mathrm{KCl}, 1.2 \mathrm{Na}_{2} \mathrm{HPO}_{4}, 2.4 \mathrm{MgSO}_{4}, 0.0 \mathrm{CaCl}_{2}$, 5.6 glucose, $0.02 \mathrm{EDTA}$, and 2.0 MOPS, pH 7.4) 15 min before digestion to reduce activation due to mechanical perturbation during isolation. The vessel was then cut transversely into 1- to 3-mm strips, consistent with the orientation of the long axis of the SMCs. These strips were placed in prewarmed $\left(37^{\circ} \mathrm{C}\right) \mathrm{Ca}^{2+}-$ free PSS containing papain $(20 \mathrm{U} / \mathrm{ml})$ in a shaking water bath $(50 \mathrm{cycles} / \mathrm{min})$ for $10 \mathrm{~min}$. After digestion, the strips were rinsed with fresh $\mathrm{Ca}^{2+}{ }^{+}$free PSS and then the medial layer was carefully teased apart, liberating single SMCs.

\section{Single cell contractions.}

Mechanical measurements were performed in a flow-through chamber consisting of a depression slide with three inputs and one output. The concave depression on the slide was surrounded by a wax ring to prevent fluid dispersal during movement of micropipettes within the solution for cell manipulation. The gravity-feed flow through the input tubes was monitored by inclusion of fast green $(0.002 \% \mathrm{wt} / \mathrm{vol})$ in the perfusion solutions. Outflow from the perfusion chamber was controlled by a peristaltic pump (Rabbit Miniplus 2, Rainin Instrument, Emeryville, CA). Output was matched to input by adjusting the speed of the peristaltic pump so that the chamber fluid meniscus remained at a constant level.

Single SMCs were isolated from vascular tissue (aorta and carotid) by the methods detailed in Cell isolation. The SMCs were transferred from coated glass isolation dishes (Sigmacote, Sigma, St. Louis, MO; Slickcoat, Intermountain Scientific, Kaysville, UT) via wide-bore pipettes to the depression slides. Cells were allowed to settle to the bottom of the slide ( $5 \mathrm{~min}$ ) before solution exchange from $\mathrm{Ca}^{2+}$-free PSS to relaxing buffer ( $\mathrm{pCa}$ 9.0) [relaxing buffer contained (in $\mathrm{mM}) 14.5$ creatine phosphate, 7 ethylene glycol-bis ( $\beta$-aminoethyl ether)- $N, N, N^{\prime}, N^{\prime}$-tetraacetic acid (EGTA), 20 imidazole, 1 free $\mathrm{Mg}^{2+}$, 4 free MgATP, $5.42 \mathrm{MgCl}_{2}, 79.16 \mathrm{KCl}$, and 4.74 ATP and $16.33 \mu \mathrm{M} \mathrm{CaCl}_{2}, \mathrm{pH}$ 7.0]. Once cells were in the relaxing buffer, permeabilization of the SMC membrane was accomplished by one of three methods:1) 5-min incubation in relaxing buffer + 250 hemolytic $\mathrm{U} / \mathrm{ml}$ staphylococcal $\alpha$-toxin ( $\alpha$-toxin) $\left.)^{4}, 2\right) 10$-min incubation in relaxing buffer + $250 \mathrm{U} / \mathrm{ml} \alpha$-toxin, or 3) 10-min incubation in relaxing buffer $+35 \mu \mathrm{g} / \mathrm{ml}$ saponin. $\frac{38}{}$ After permeabilization, all SMCs were washed with relaxing buffer $(2 \mathrm{~min})$.

After washing was completed, a permeabilized SMC was selected on the basis of morphology ${ }^{9}$ and birefringence of the cell membrane using phase-contrast microscopy. The cell was attached to a small bore (1- to 3- $\mu \mathrm{m}$ tip) glass micropipette by close apposition of the pipette tip and gentle suction. Once attached, the SMC was lifted off the chamber floor, to ensure absence of adhesion, and stimulated with an activation cocktail consisting of $1 \mu \mathrm{M}$ phenylephrine and 1 $\mu \mathrm{M}$ histamine in activating buffer ( $\mathrm{pCa}$ 6.0) [activating buffer contained (in $\mathrm{mM}$ ) 14.5 creatine phosphate, $7 \mathrm{EGTA}, 20$ imidazole, 1 free $\mathrm{Mg}^{2+}$, 4 free MgATP, $5.31 \mathrm{MgCl}_{2}, 68.55 \mathrm{KCl}, 4.79 \mathrm{ATP}$, and $\left.4.91 \mathrm{CaCl}_{2}, \mathrm{pH} 7.0\right]$.

Permeabilized cells were also activated with two different $\mathrm{Ca}^{2+}$ concentrations without the other agonists to determine if the cells were being fully activated. No differences were 
observed with $10^{-5} \mathrm{M} \mathrm{Ca}^{2+}, 10^{-6} \mathrm{M} \mathrm{Ca}^{2+}$, or $10^{-6} \mathrm{M} \mathrm{Ca}^{2+}$ with the two agonists. All cells reported in this study were activated with the full cocktail $\left(10^{-6} \mathrm{M} \mathrm{Ca}^{2+}, 1 \mu \mathrm{M}\right.$ phenylephrine, and $1 \mu \mathrm{M}$ histamine). As an additional control, five cells were activated with the activating cocktail that also included $1 \mu \mathrm{M}$ okadaic acid, a myosin light chain (MLC) phosphatase inhibitor. $\underline{3}$

\section{Cell length data acquisition.}

Before and throughout the single SMC contraction, cell length was continuously monitored by a charge-coupled device (CCD) camera (XC-75, Sony, Park Ridge, NJ) attached to an inverted microscope $(\times 320$; Fluovert, Leitz, Overland Park, KS). The output from the CCD camera was recorded by a video recorder (EV-S3000, Sony, Park Ridge, NJ) on 8-mm videotape. SMC images from the 8-mm tape were captured by a frame grabber (Data Translation, Marlborough, MA) in conjunction with NIH Image software (version 1.31; National Institutes of Health, Bethesda, MD) at regular intervals encompassing the SMC contraction. Image analyses were performed using NIH Image software (version 1.59). Each frame of the cell from successive time points was brought up on the computer screen. The ends of the cell were identified on the frame. Using the mouse and starting at one end of the cell, we marked the midpoint of the cell's width along its entire length at 5 - to $10-\mu \mathrm{m}$ intervals (see Fig. $\underline{3}$ ). The length of the line connecting these points gave total cell length for each frame. This method gives an accurate measurement of cell length independent of linearity.

\section{Untethered velocity measurements from single SMCs.}

Video images from the CCD camera were recorded on a videocassette recorder, digitized, imported into a personal computer, and analyzed with respect to length over a discrete time frame using NIH Image software (version 1.59). Of the 53 cells examined, 28 exhibited the following criteria: 1) characteristic morphology of contracted SMCs (i.e., evaginations in cell membrane postcontraction $)^{9}$ and2) a smooth sigmoidal decrease in length over time, indicating unconstrained contraction within the plane of focus of the microscope. Unloaded shortening velocity was taken from the steepest slope of a plot of length vs. time (see Fig. 2) for these 28 cells and plotted against their SM2-to-SM1 mRNA ratio. After its contraction, each cell from which mechanical measurements were made was transferred to a microcentrifuge tube so that the SM2-to-SM1 mRNA ratio could be determined. This allowed both the mechanical measurements and the RT-PCR to be performed on the same cell.

\section{RT-PCR.}

The methods used are those of Meer and Eddinger. ${ }^{24}$ Briefly, single SMCs were transferred to a microcentrifuge tube via a micropipette and lysed by a freeze/thaw cycle. Ten microliters of RT reaction mix [ $5 \times \mathrm{RT}$ buffer (US Biochemical, Cleveland, $\mathrm{OH}$ ), $0.02 \mu \mathrm{g} / \mu \mathrm{l}$ oligo(dT) (Promega, Madison, WI), $2 \mathrm{U} / \mu \mathrm{l}$ RNasin (Promega), $0.1 \mu \mathrm{g} / \mu \mathrm{l}$ acetylated bovine serum albumin, $500 \mu \mathrm{M}$ dNTP, $1.23 \mathrm{mM}$ dithiothreitol, and $10 \mathrm{U} / \mu \mathrm{l}$ Moloney murine leukemia virus-RT (US Biochemical)] were added to each tube and incubated at $37^{\circ} \mathrm{C}$ for $2 \mathrm{~h}$. PCR reaction mix [TaqDNA polymerase 10x reaction buffer (Promega), $1.8 \mathrm{mM} \mathrm{MgCl}_{2}, 50 \mu \mathrm{M}$ dNTP, $1 \mu \mathrm{M} 5^{\prime}$ primer, $1 \mu \mathrm{M}$ 3' primer, and 1 unitTaq polymerase (Promega)] was added to each tube to a final volume of $50 \mu \mathrm{l}$. The primers used corresponded to rabbit smooth muscle myosin 1 (nucleotide positions 5627-5646 and 5917-5898; Operon, Alameda, CA). Sixty cycles of amplification were performed, using the following temperature profile: $94^{\circ} \mathrm{C}(1 \mathrm{~min}, 30 \mathrm{~s}), 55^{\circ} \mathrm{C}(2 \mathrm{~min})$, and $72^{\circ} \mathrm{C}$ 
(3 min). An additional unit of Taqpolymerase was added after the first 30 PCR cycles. Controls performed indicate the SM2-to-SM1 mRNA ratio is an excellent predictor of the SM2-to-SM1 protein ratio $(r=0.92)$ and that these methods are reliable, reproducible, sensitive, and accurate. $\underline{24}$

\section{Electrophoresis and densitometry.}

PCR products were separated by electrophoresis on $8 \%$ acrylamide gels ${ }^{11}$ and visualized under ultraviolet light after staining with ethidium bromide $(1 \mu \mathrm{g} / \mathrm{ml})$. Band intensity was quantitated by image analysis of gel photographs using Ambis 2000 software (Ambis, San Diego, CA).

\section{RESULTS}

Assessment of the functional significance of the differential expression of SM1 and SM2 MHC isoforms was addressed by examining the contractile properties of isolated SMCs from which the relative levels of SM1 and SM2 mRNA were determined by RT-PCR. We have previously shown that RT-PCR is an accurate and precise method of measuring the relative levels of SM1 and SM2 mRNA and that the relative levels of SM2/SM1 mRNA correlate well with the relative

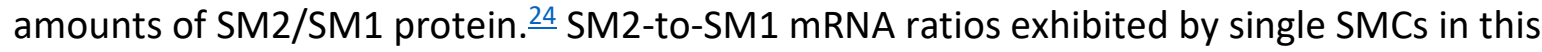
study ranged from $0.07-0.60$ [ $n=28$, mean value of $0.33 \pm 0.16$ (SD)]. An example of the PCR products amplified from single arterial SMCs is shown in Fig.1. Table 1 gives the raw values for the bands shown in Fig. 1 and the SM2-to-SM1 ratio for each of the seven cells.

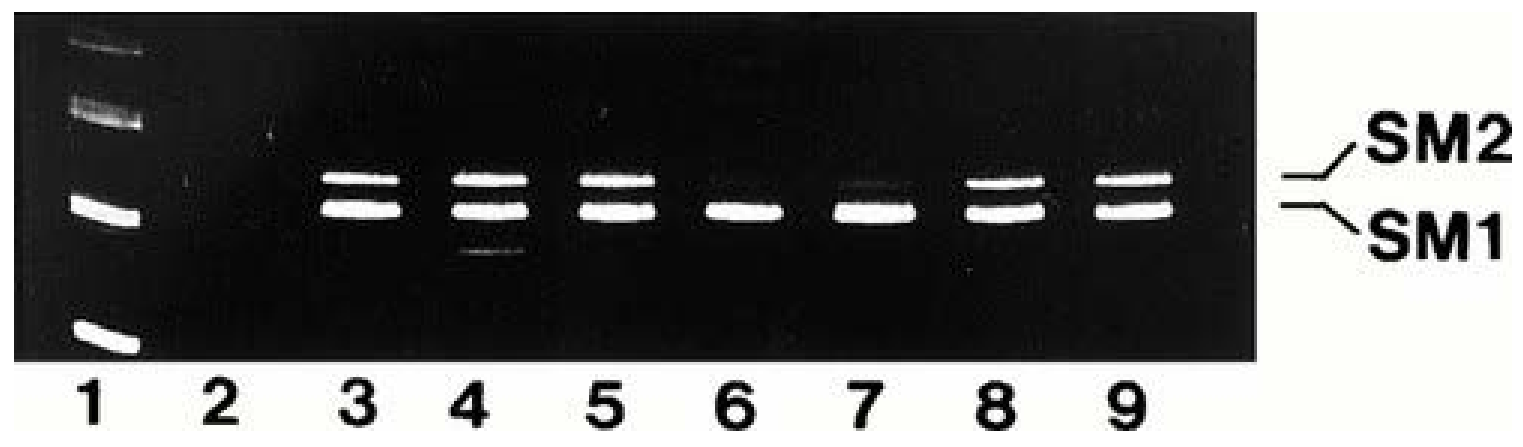

Fig. 1.

Single smooth muscle cell (SMC) SM2/SM1 polymerase chain reaction (PCR) products. Individual SMCs were utilized for reverse transcription (RT)-PCR, as described in methods, to correlate contractile properties of individual cells with their myosin heavy chain expression profile. RT-PCR products from 7 single cells isolated from the same rabbit aorta are shown in lanes 3-9. SM2-to-SM1 ratios for the 7 cells shown range from a high of 0.55 in lane 4 to a low of 0.03 in lane 7. A 123-base pair (bp) DNA ladder was run in lane $1 ; 123-, 246-$, and $492-$ bp bands are shown. Lane 2 contains the same RT-PCR reaction mix used on the 7 cells; however, mRNA was omitted. 
Table 1. Raw data and ratios for SM2/SM1 for single smooth muscle cells shown in Fig. $\underline{1}$

\begin{tabular}{llll}
\hline Lane & SM2 & SM1 & SM2-to-SM1 Ratio \\
\hline 3 & 15,015 & 41,430 & 0.36 \\
4 & 21,841 & 38,225 & 0.55 \\
5 & 22,336 & 44,796 & 0.50 \\
6 & 3,404 & 47,897 & 0.07 \\
7 & 1,864 & 60,025 & 0.03 \\
8 & 15,261 & 37,569 & 0.41 \\
9 & 17,246 & 30,911 & 0.46
\end{tabular}

Viability of isolated SMCs was determined by two criteria:1) a smooth, bright plasma membrane when viewed with phase-contrast microscopy as described by Driska and Porter (ㄱ) and Fay and Delise ${ }^{9}$ and2) a smooth sigmoidal contraction after exposure to the activating cocktail (Fig. 2), indicating an unconstrained contraction. Because we are unaware of a method capable of determining the phosphorylation state of the 20-kDa MLCs in single SMCs, we adopted a stimulation protocol that would theoretically produce maximal contractions in isolated SMCs. Permeabilized single SMCs were exposed to a cocktail containing $1 \mu \mathrm{M}$ free $\mathrm{Ca}^{2+}$ (pCa 6.0), $1 \mu \mathrm{M}$ phenylephrine, and $1 \mu \mathrm{M}$ histamine. Individually, each of these compounds at these concentrations should produce a maximal contraction of SMCs, as they do at the tissue level. In concert, these substances should alleviate any intercellular differences in second messenger systems by direct activation as well as multiple receptor-operated mechanisms. No observable differences were noted between permeabilized cells activated with $10^{-5} \mathrm{M} \mathrm{Ca}^{2+}$, $10^{-6} \mathrm{M} \mathrm{Ca}^{2+}$, or $10^{-6} \mathrm{M} \mathrm{Ca}^{2+}$ with $1 \mu \mathrm{M}$ phenylephrine and histamine. An example of a typical single vascular SMC contraction is shown in Fig. $\underline{3}$. In addition, five cells were activated with the activating cocktail, which included $1.0 \mu \mathrm{M}$ okadaic acid. These cells shortened at rates $[n=5$, average velocity $=1.1 \pm 0.66(\mathrm{SD}) \mu \mathrm{m} / \mathrm{s}$, minimum value $=0.44$, maximum value $=1.84]$ that were not significantly different from cells activated without the okadaic acid (see below). 


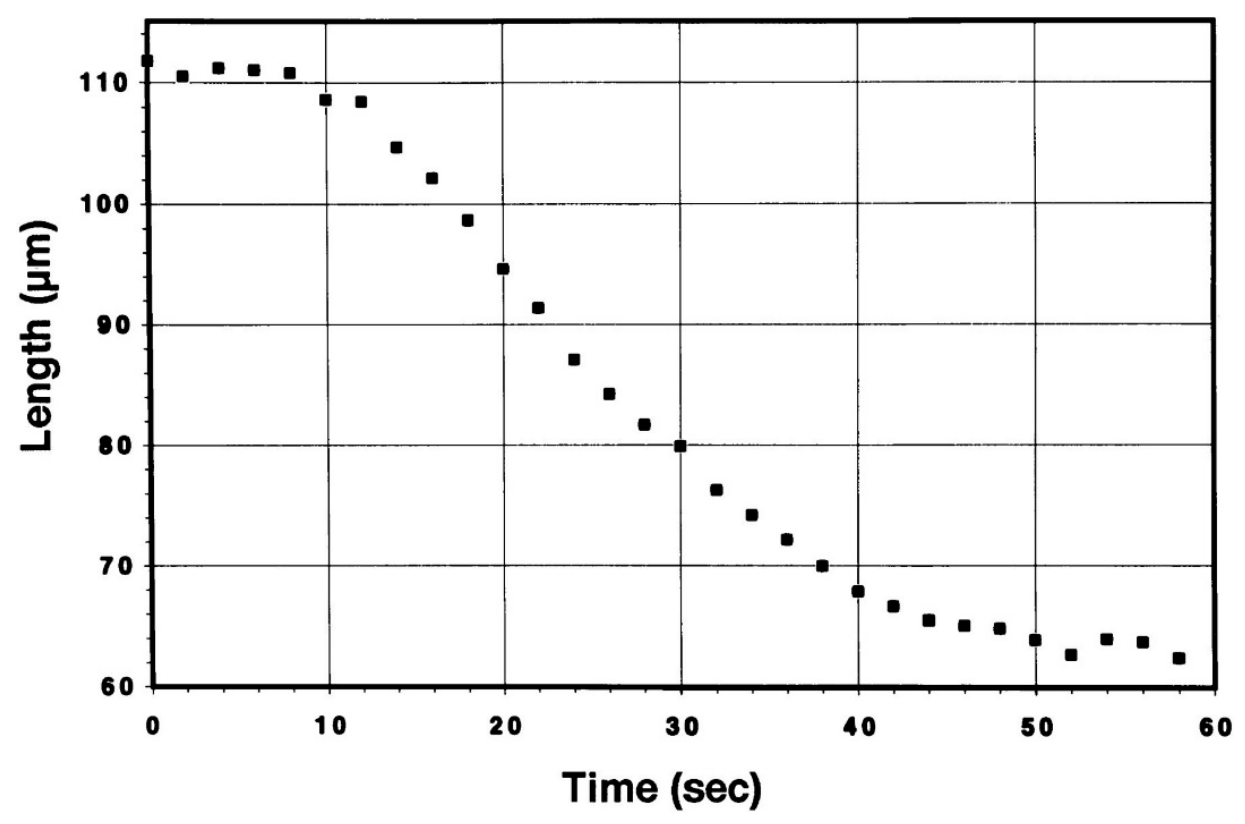

Fig. 2.

Measurement of single SMC length during untethered shortening. Record of the optical measurement of the length of an $\alpha$-toxin-permeabilized ( $5 \mathrm{~min}$ ) SMC following activation with $\mathrm{Ca}^{2+}$ (pCa 6.0), phenylephrine $(1 \mu \mathrm{M})$, and histamine $(1 \mu \mathrm{M})$ is shown. Cell was suspended from a micropipette and was not in contact with the bottom of the chamber.

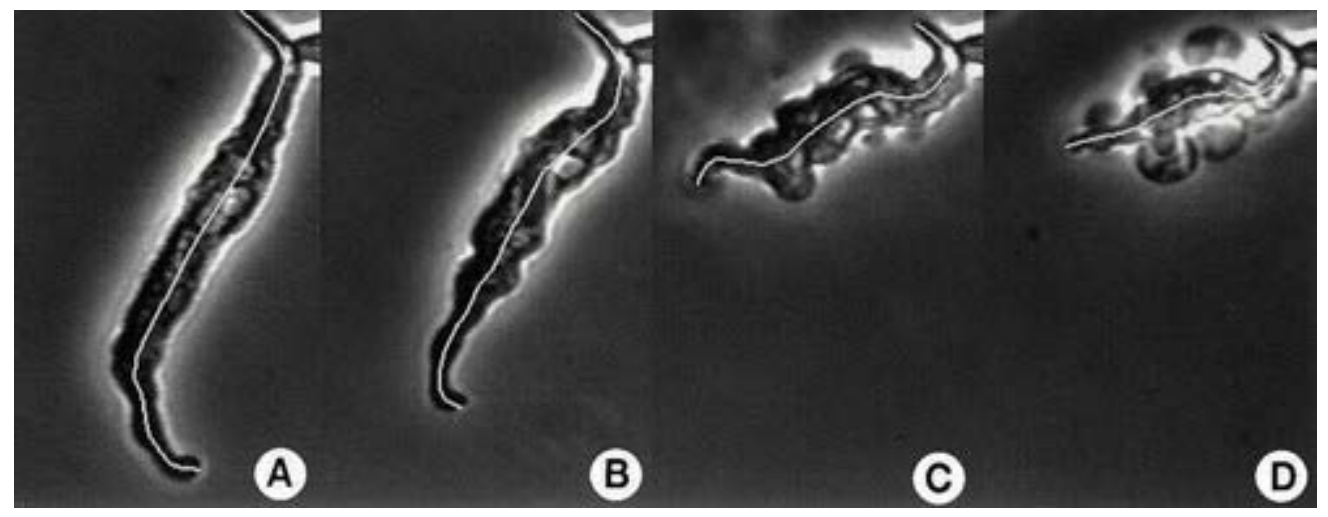

Fig. 3.

Contraction of a single SMC. A temporal series of digitized images of a permeabilized SMC contracting in response to exposure to an activating solution containing $\mathrm{Ca}^{2+}(\mathrm{pCa} 6.0)$, phenylephrine $(1 \mu \mathrm{M})$, and histamine $(1 \mu \mathrm{M})$ is shown. Cell length in $A$, before activation, was $123 \mu \mathrm{m}$. Time for $A-D$ was $0,14,32$, and $50 \mathrm{~s}$, respectively. A segmented line drawn through the middle of the cell from end to end shows the measured length for each cell.

To assess the efficacy of isolated SMC permeabilization, three different permeabilization protocols were utilized in this study. The first method was modified from Brozovich (4), in which isolated SMCs are exposed to staphylococcal $\alpha$-toxin (250 hemolytic U/ml) for 5 min in a low- $\mathrm{Ca}^{2+}$ physiological buffer. Thirteen of 28 viable cells were permeabilized in this fashion. The average velocity of these cells was $1.10 \pm 0.58$ (SD) $\mu \mathrm{m} / \mathrm{s}(n=13$, minimum value $=0.26 \mu \mathrm{m} / \mathrm{s}$, 
maximum value $=1.85 \mu \mathrm{m} / \mathrm{s}$ ). Permeabilization of the SMC plasma membrane was confirmed via the use of trypan blue dye. Trypan blue is excluded from intact cells. Two other permeabilization methods were utilized to confirm that the SMCs were being adequately permeabilized to assure maximum activation. Seven SMCs were permeabilized with $\alpha$-toxin $(250 \mathrm{U} / \mathrm{ml})$ for twice the previous exposure time $(10 \mathrm{~min})$; the peak velocities of these cells were not significantly different compared with the cells exposed to $\alpha$-toxin for $5 \mathrm{~min}$ [paired Student's $t$-test, $P<0.05, n=7$, mean value of $1.12 \pm 0.58$ (SD) $\mu \mathrm{m} / \mathrm{s}$, minimum $=0.47 \mu \mathrm{m} / \mathrm{s}$, maximum $=2.06 \mu \mathrm{m} / \mathrm{s}$ ]. Because the two $\alpha$-toxin data sets were overlapping, even though the permeabilization protocol was slightly different, the sets were combined for data analyses and comparisons. The final permeabilization protocol was modified from Walsh et al., $\underline{38}$ which involved a $15-\mathrm{min}$ permeabilization with saponin $(35 \mu \mathrm{g} / \mathrm{ml})$. Due to basic differences in the mechanisms of permeation between $\alpha$-toxin and saponin and a slightly lower, but not significantly different, average peak velocity $(0.80 \mu \mathrm{m} / \mathrm{s})$, the saponin-permeabilized cells were regarded as a separate data set.

The 28 viable, permeabilized cells were examined with respect to initial length (before activation), final length (minimum length), peak unloaded shortening (maximum rate of shortening), total length change (initial length - minimum length) and SM2/SM1 mRNA expression levels. The mechanical and the molecular measurements were both performed on the same cells. The various physical measurements were all correlated with the SM2/SM1 mRNA level of the individual cells. Data from cells permeabilized with staphylococcal $\alpha$-toxin are shown in Fig. $4, A-D$. Data from cells permeabilized with saponin are shown in Fig. $\underline{5}, A-D$. Data from correlational analysis with SM2-to-SM1 mRNA ratio using linear regression (leastsquares method) are recorded in Table 2 ; $t$-tests were performed on the various coefficients of correlation to determine if the null hypothesis could be rejected. At the $P<0.05$ level withn -2 degrees of freedom, the null hypothesis was rejected in the case of the relationship between the SM2-to-SM1 ratio and final cell length (both $\alpha$-toxin- and saponin-permeabilized cells), making this correlation significant. All the other correlations shown in Figs. $\underline{4}$ and $\underline{5}$ are not significant. 
A

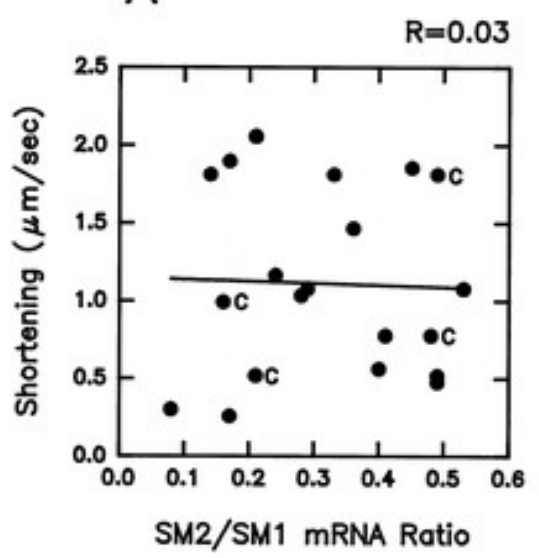

C

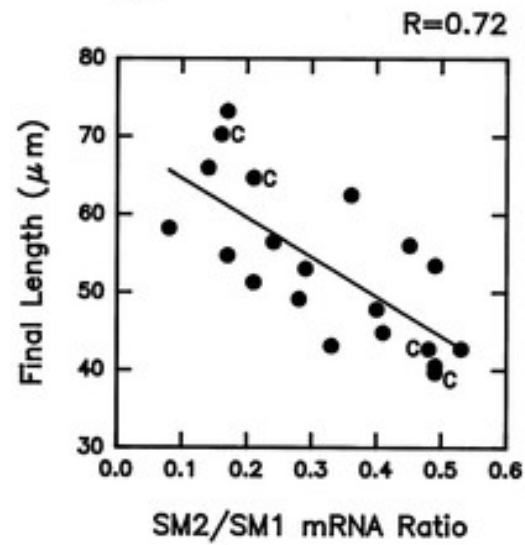

B

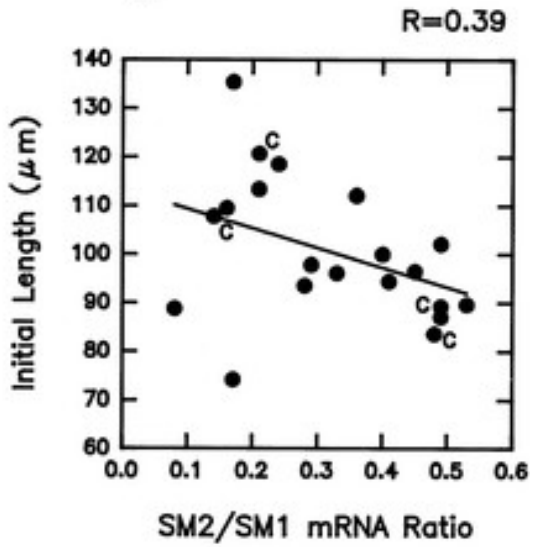

D

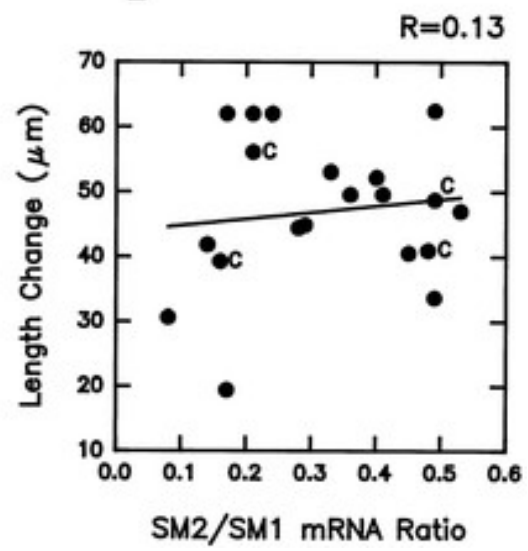

Fig. 4.

Velocity and length changes in $\alpha$-toxin-permeabilized SMCs during untethered shortening and their correlations to the SM2-to-SM1 ratio. Twenty (total) single SMCs isolated from rabbit vasculature (aorta or carotid) and permeabilized with $\alpha$-toxin ( 250 hemolytic $\mathrm{U} / \mathrm{ml}$ ) were activated with activating solution (seemethods; pCa 6.0, $1 \mu \mathrm{M}$ phenylephrine, $1 \mu \mathrm{M}$ histamine) while suspended in solution from one end by a suction micropipette. Cell length and velocity of shortening were measured and compared with the RT-PCR-generated SM2-to-SM1 mRNA ratio. A: correlation between maximal shortening velocity $\left(V_{\max }\right)$ and SM2/SM1. Correlations between initial length $(B)$, final length $(C)$, and total change in length $(D)$ with SM2-to-SM1 ratio are also shown. Line through data for $A-D$ is best fit with $r$ value given (top right). C, carotid cells. All other cells were from the aorta. 
A

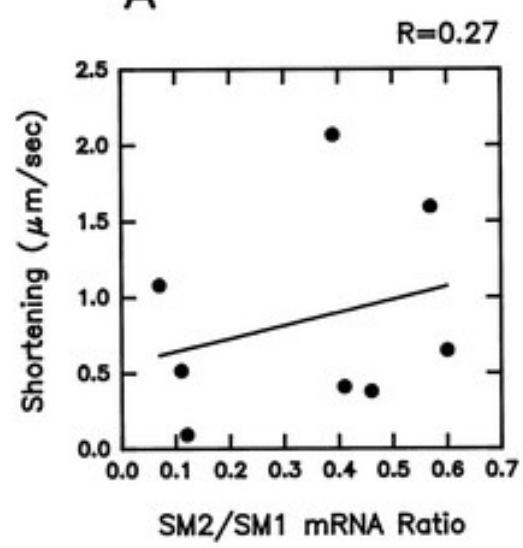

C

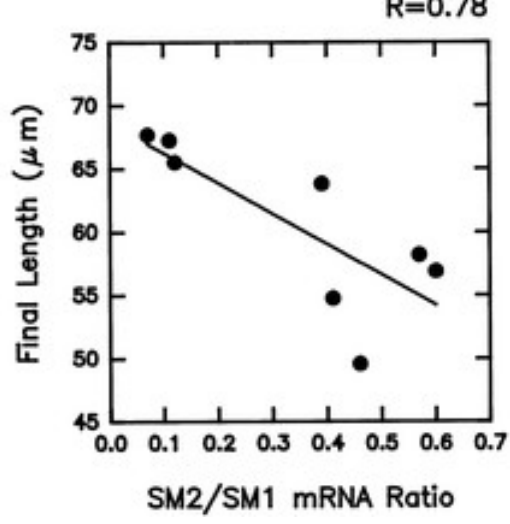

B

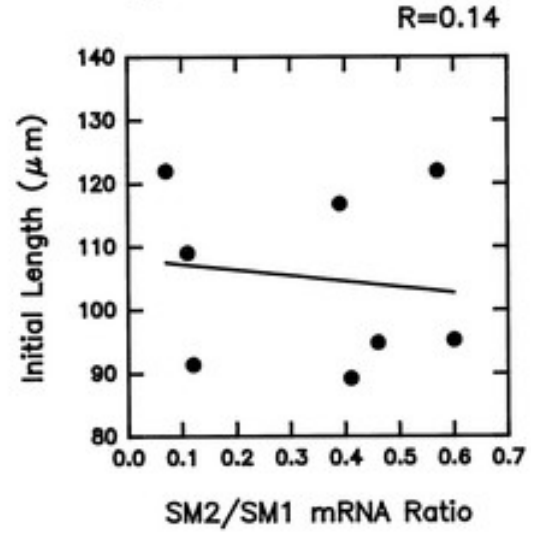

D

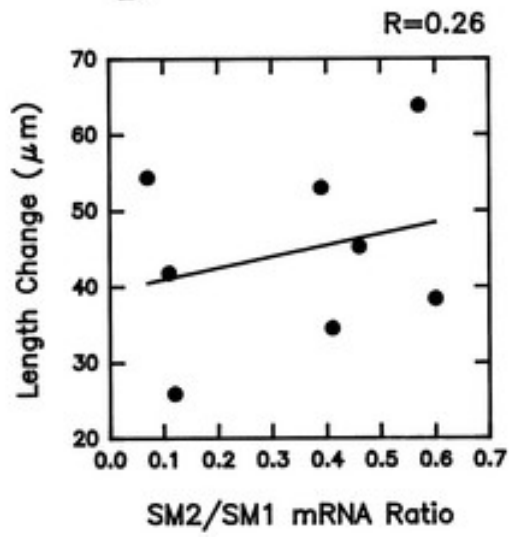

Fig. 5.

Velocity and length changes in saponin-permeabilized SMCs during untethered shortening and their correlations to SM2/SM1. Eight single SMCs isolated from rabbit aorta and permeabilized with saponin $(35 \mu \mathrm{g} / \mathrm{ml}$ ) were activated with activating solution (seemethods; pCa 6.0, $1 \mu \mathrm{M}$ phenylephrine, $1 \mu \mathrm{M}$ histamine) while suspended in solution from one end by a suction micropipette. Cell length and velocity of shortening were measured and compared with the RT-PCR-generated SM2-to-SM1 mRNA ratio. A: correlation between $V_{\max }$ and SM2/SM1. Correlations between initial length $(B)$, final length $(C)$, and total change in length $(D)$ with SM2-to-SM1 ratio are also shown. Line through data for $A-D$ is best fit with rvalue given (top right).

Table 2. Correlations of contraction characteristics with SM2-to-SM1 ratio Variable Correlated with SM2-to-SM1 Ratio $r$ Value, $\alpha$-toxin treated $(n=20) r$ Value, saponin-treated $(n=8)$

\begin{tabular}{lll}
\hline Peak velocity, $\mu \mathrm{m} / \mathrm{s}$ & 0.03 & 0.27 \\
Initial length, $\mu \mathrm{m}$ & 0.39 & 0.14 \\
Final length, $\mu \mathrm{m}$ & $0.72^{ \pm}$ & $0.78^{*}$ \\
Length change, $\mu \mathrm{m}$ & 0.13 & 0.26
\end{tabular}

"Significant at $P<0.05$.

${ }^{\dagger}$ Significant at $P<0.01$. 


\section{DISCUSSION}

The physiological significance of the SM1 and SM2 SM-MHC tail isoforms was investigated in this study by examining the relationship between SM2/SM1 mRNA expression levels and the characteristics of untethered shortening in contracting single SMCs. Untethered shortening velocity measurements of SMCs suspended in solution provide the best approximation of shortening under zero load. The use of micromolar free $\mathrm{Ca}^{2+}$ to activate isolated, permeabilized SMCs exceeds the reported requirement of $0.36 \mu \mathrm{M} \mathrm{Ca}^{2+}$ for maximal contractile response in isolated, permeabilized feline esophageal SMCs. $\frac{34}{3}$ The fact that three different permeabilization protocols yield unloaded shortening values that are not significantly different $(P<0.05)$ also suggests that these are maximal contraction rates. The intact isolated SMCs are not activated by external $\mathrm{Ca}^{2+}(1.6 \mathrm{mM})$, and the permeabilized isolated SMCs do not contract unless they are exposed to $\mathrm{Ca}^{2+}$.

Because we are unaware of a method for quantitation of MLC phosphorylation at the single cell level, we chose to achieve maximum activation by direct (with $\mu \mathrm{M}$ concentrations of $\mathrm{Ca}^{2+}$ ) and indirect (with $\mu \mathrm{M}$ concentrations of phenylephrine and histamine) mechanisms to ensure this result. To further validate this assumption, five cells were activated with the same activating cocktail solution to which $1.0 \mu \mathrm{M}$ okadaic acid was added. At this concentration, okadaic acid has been reported to be a PP-1 protein phosphatase-type inhibitor, which includes the MLC phosphatase. $\frac{3}{}$ No differences in mechanical responses were observed for cells activated with or without the okadaic acid included in the activating cocktail, suggesting that we have maximally activated these cells and differences in shortening velocities are not due to differences in MLC phosphorylation.

The methods used in this study significantly increase the types of questions that may be addressed relative to previous experimental designs. As has been previously shown, $\underline{24}$ there is extensive heterogeneity with regard to the SM-MHC tail isoforms between individual SMCs in the same tissue. Thus multicellular experiments are limited to providing averaged information from a wide range of cells exhibiting different levels of contractile protein isoforms. ATPase measurements and in vitro motility measurements are done outside of the native structural organization of the cell. Thus possible intermolecular effects may not be examined. The methods used in this study allow mechanical measurements to be made on a threedimensionally intact cell and to measure the relative amounts of various protein isoforms from the same cell (via mRNA levels). This avoids potential problems of intercellular variability, while keeping the three-dimensional structure and intracellular protein arrangement intact.

Previous attempts with multicellular preparations have failed to establish a definitive relationship between SM2/SM1 content and velocity in smooth muscles. Sparrow et al. $\frac{35}{}$ and Hewett et al. ${ }^{14}$ have shown small positive correlations between SM1 MHC content and $V_{\max }$ in rat myometrial muscle. However, Morano et al. $\underline{25}$ have shown $V_{\max }$ to correlate with LC17a content and not SM1 or SM 2 content in the same tissue. Cai et al. $\underline{5}$ have shown that incubation with synthetic peptide identical to a portion of the nonhelical tail unique to SM1 significantly reduced $V_{\max }$ in permeabilized smooth muscles. This last finding is in opposition to the earlier findings that SM1 exhibits a positive correlation with $V_{\max } \cdot \underline{14}, \underline{35}$ This study shows no significant correlation between SM2/SM1 mRNA expression and unloaded shortening at the single SMC 
level (Figs. $\underline{4} A$ and $\underline{5} A$; Table $\underline{2}$ ). These data support the conclusion of Morano et al. $\underline{25}$ that in uterine tissue $V_{\max }$ does not correlate with SM-MHC tail isoform content. This finding is also in agreement with data showing no difference in the rate of actin filament sliding in the in vitro motility assay by bovine aortic SM1 and SM2. $\underline{20}$ This result extends the previous data 20 by examining the myosin isoforms in their native environment, where intermolecular interactions can still occur but intercellular heterogeneity is not a problem.

The best correlation between SM2/SM1 isoform content and the physical characteristics of vascular SMCs during untethered shortening was with the final postcontraction length of the SMC (Figs. $\underline{4} C$ and $\underline{5} C$, Table $\underline{1}, r=0.72$ for $\alpha$-toxin-permeabilized cells and $r=0.78$ for saponinpermeabilized cells). Thus an increased SM2 isoform expression appears to impart to the SMC the ability to attain a shorter final length following maximal contraction. The difference region between SM1 and SM2 occurs at the $3^{\prime}$ end of the myosin molecule, an area of the MHC that has been shown to be very important in the process of myosin filament formation. Proteolytic cleavage, $\underline{15}, \underline{31}$ antibody binding,,$\underline{6}$ and phosphorylation $6 a^{\prime}{ }^{17,}, 21-23$ of this region influence both myosin filament nucleation and structure. The synthetic myosin filaments formed from mixtures of myosin isoforms isolated from smooth and skeletal muscles exhibit lengths intermediate between the longer skeletal filaments and the shorter smooth filaments. $\underline{16}, \underline{28}, \underline{37}$ Experiments performed at near physiological $\mathrm{pH}$ (pH 6.5-7.0) generated "hybrid" filaments with a unimodal length distribution, with shorter average lengths as the percentage of smooth or nonmuscle myosin increased. $\underline{16}, \underline{28}, \underline{37}$ The unimodal nature of these length distributions indicates the presence of a single population of filaments composed of both smooth or nonmuscle myosin isoforms and skeletal myosin. Another indication of the uniform incorporation of both smooth and skeletal myosins into these hybrid filaments is the fact that paracrystals composed of these filaments exhibit a single axial repeat pattern. $\frac{37}{}$

If smooth and skeletal myosins can copolymerize to generate myosin filaments with varying lengths, then it is also possible that copolymerization of the SM-MHC isoforms, SM1 and SM2, may generate filaments with varying lengths. The incorporation of increasing amounts of SM2 into cellular myosin filaments may reduce the lengths of these filaments. These shorter SM2containing filaments may allow force generation at shorter lengths, extending the lengthtension curve of cells containing SM2 to the left and thereby allowing SMCs with SM2 to attain shorter final lengths. Although the possibility of shorter SM1/SM2 hybrid filaments may not be the only mechanism responsible for the shorter minimal lengths of SMCs with higher levels of SM2 expression, it is certainly plausible. We are not proposing that any given myosin filament can span the entire length or width of the SMC. However, several of these hybrid filaments in series may allow increased force production as the SMC approaches its minimum length due to reduced steric hindrance. This could result from compression of the intracellular contents and interaction with dense bodies and/or intermediate filaments. Another factor that may be playing a role is the proposed remodeling of the contractile proteins of SMCs at shorter lengths. $\underline{\underline{13}}$ It is possible that at shorter initial lengths the cytoskeleton is remodeled to allow maximum shortening when activated; however, once activated and under strain the contractile elements cannot rearrange to optimize shortening. If this applies to the initial lengths of the SMCs in this study, the contribution to final length would be small, as the correlation between SM2/SM1 expression and initial length was not significant at the $5 \%$ level (Table 2). Our current 
model for the effect of SM2/SM1 expression on the minimum length an SMC can attain following untethered shortening is that hybrid SM2/SM1 myosin filaments are structurally different from SM1 myosin filaments, thereby permitting the greater extent of shortening exhibited by SMCs with higher levels of SM2 expression.

There are other possible explanations as well. Myosin filament stability may be affected by the amount of SM1 and SM2 MHC they contain. This could allow some filaments to disassemble and reassemble at shorter lengths and thus increase total cell shortening. These filaments may also have different affinities for other cytoskeletal proteins that provide for the scaffolding of cells. A third possibility includes regional localization and/or regulation of these filaments either via phosphorylation or other mechanisms that could affect cell shortening. Further work is needed to test these hypotheses.

We have reported previously $\underline{24}$ that there is extreme heterogeneity in the ratio of the SM2/SM1 $\mathrm{MHC}$ tail isoforms present in single cells from a given vessel. Here, we report that this difference does not correlate with unloaded shortening velocity but does correlate with how much the cell shortens. These results, in light of reports of regional localization of unique cell populations, $\underline{10}, \underline{12}$ suggest unique functional roles for cells with different levels of SM1 and SM2 expression. During vascular constriction, the adventitial portion of the smooth muscle layer contracts to a greater extent than the intimal portion, resulting in the formation of periluminal ridges. This folding of the intimal regions of the vascular wall allows the maintenance of a circular luminal cross section and continuous blood flow during vasoconstriction. $\frac{33}{\text { If }} \mathrm{SM} 2$ expression is higher in SMCs localized near the adventitial aspect of the vascular smooth muscle layer, as suggested by Frid et al., $\underline{10}$ then the shorter final lengths these cells can attain may play a role in the disproportionate shortening of this layer with respect to the luminal aspect. $\frac{33}{3}$ Clearly, there are other possible explanations for the results reported in this paper. Further use of these single cell methods in conjunction with structural studies (i.e., immunoelectron microscopy, in situ hybridization) should provide answers to the functional significance of these and other contractile protein isoforms in SMCs.

This work was supported by grants from the National Institutes of Health.

\section{AUTHOR NOTES}

Address for reprint requests: T. J. Eddinger, Dept. of Biology, Marquette Univ., WLS 109, PO Box 1881, Milwaukee, WI 53201-1881.

\section{References}

1. Babij P. , Kelley C. , Periasamy M. .Characterization of a mammalian smooth muscle heavy-chain gene: complete nucleotide and protein coding sequence and analysis of the 5' end of the gene..Proc. Natl. Acad. Sci. USA 88: 10676-10680, 1991.

2. Babij P. , Periasamy M. .Myosin heavy chain isoform diversity in smooth muscle is produced by differential RNA processing..J. Mol. Biol. 210: 673-679, 1989. 
3. Bialojan C. , Rüegg J. C. , Takai A. .Effects of okadaic acid on isometric tension and myosin phosphorylation of chemically skinned guinea pig taenia coli..J. Physiol. (Lond.) 398: 81-95, 1988.

4. Brozovich F. V. .PKC regulates agonist-induced force enhancement in single $\alpha$-toxinpermeabilized vascular smooth muscle cells..Am. J. Physiol. Cell Physiol. 37 268: C1202C1206, 1995.

5. Cai S. , Ferguson D. G. , Martin A. F. , Paul R. J. .Smooth muscle contractility is modulated by myosin tail-S2-LMM hinge region interaction..Am. J. Physiol. Cell Physiol. 38 269: c1126-C1132, 1995.

6. Citi S. , Kendrick-Jones J. .Studies on the structure and conformation of brush border myosin using monoclonal antibodies..Eur. J. Biochem. 165: 315-325, 1987.

(a)Collins J. H. , Kuznicki J. , Bowers B. , Korn E. D. .Comparison of the actin binding and filament formation properties of phosphorylated and dephosphorylated Acanthamoeba myosin II..Biochemistry 21: 6910-6915, 1982.

7. Driska S. P. , Porter R. .Isolation of smooth muscle cells from swine carotid artery by digestion with papain..Am. J. Physiol. Cell Physiol. 20 251: C474-C481, 1986.

8. Eddinger T. J. , Murphy R. A. .Two smooth muscle myosin heavy chains differ in their light meromyosin fragment..Biochemistry 27: 3807-3811, 1988.

9. Fay F. S., Delise C. M. .Contraction of isolated smooth-muscle cells-structural changes..Proc. Natl. Acad. Sci. USA 70: 641-645, 1973.

10. Frid M. G. , Moiseeva E. P. , Stenmark K. R. .Multiple phenotypically distinct smooth muscle cell populations exist in the adult and developing bovine pulmonary arterial media in vivo..Circ. Res. 75: 669-681, 1994.

11. Giulian G. G. , Moss R. L. , Greaser M. L. .Improved methodology for analysis and quantitation of proteins on one-dimensional silver-stained slab gels..Anal.

Biochem. 129: 277-287, 1983.

12. Giuriato L. , Scatena M. , Chiavegato A. , Tonello M. , Scannapieco G. , Pauletto P. , Sartore $S$. .Non-muscle myosin isoforms and cell heterogeneity in developing rabbit vascular smooth muscle..J. Cell Sci.101: 233-246, 1992.

13. Gunst S. J. , Meiss R. A. , Wu M.-F. , Rowe M. .Mechanisms for the mechanical plasticity of tracheal smooth muscle..Am. J. Physiol. Cell Physiol. 37 268: C1267-C1276, 1995. 
14. Hewett T. E. , Martin A. F. , Paul R. J. .Correlations between myosin heavy chain isoforms and mechanical parameters in rat myometrium..J. Physiol. (Lond.) 460: 351-364, 1993.

15. Ikebe M. , Hewett T. E. , Martin A. F. , Chen M. , Hartshorne D. J. .Clevage of a smooth muscle myosin heavy chain near its $C$ terminus by $\alpha$-chymotrypsin..J. Biol. Chem. 266: 7030-7036, 1991.

16. Kaminer B. , Szonyi E. , Belcher C. D. ."Hybrid" myosin filaments from smooth and striated muscle..J. Mol. Biol. 100: 379-386, 1976.

17. Kamm K. E. , Hsu L.-C. , Kubota Y. , Stull J. T. .Phosphorylation of smooth muscle myosin heavy and light chain..J. Biol. Chem. 264: 21223-21229, 1989.

18. Kawamoto S. , Adelstein R. S. .The heavy chain of smooth muscle myosin is phosphorylated in aorta cells..J. Biol. Chem. 263: 1099-1102, 1988.

19. Kelley C. A. , Adelstein R. S. .The 204-kDa smooth muscle myosin heavy chain is phosphorylated in intact cells by casein kinase II on a serine near the carboxyl terminus..J. Biol. Chem. 265: 17876-17882, 1990.

20. Kelley C. A. , Sellers J. R. , Goldsmith P. K. , Adelstein R. S. .Smooth muscle myosin is composed of homodimeric heavy chains..J. Biol. Chem. 267: 2127-2130, 1992.

21. Kuczmarski E. R. , Spudich J. A. .Regulation of myosin self assembly: phosphorylation of dictyostelium heavy chain inhibits formation of thick filaments..Proc. Natl. Acad. Sci. USA 77: 7292-7296, 1980.

22. Kuczmarski E. R. , Tafuri S. R. , Parysek L. M. .Effect of heavy chain phosphorylation on the polymerization and structure of dictyostelium myosin filaments.J. Cell Biol. 105: 2989-2997, 1987.

23. Larson D. M. , Fujiwara K. , Alexander R. W. , Gimbrone M. A. .Myosin in cultured vascular smooth muscle cells immunofluoresence and immunochemical studies alteration in antigenic expression..J. Cell Biol.99: 1582-1589, 1984.

24. Meer D. P. , Eddinger T. J. .Heterogeneity of smooth muscle myosin heavy chain expression at the single cell level..Am. J. Physiol. Cell Physiol. 39 270: C1819-C1824, 1996.

25. Morano I. , Erb G. , Sogl B. .Expression of myosin heavy and light chains changes during pregnancy in the rat uterus..Pflügers Arch. 423: 434-441, 1993.

26. Murakami N. , Healy-Louie G. , Elzinga M. .Amino acid sequence around the serine phosphorylated by casein kinase II in brain myosin heavy chain..J. Biol. Chem. 265: 
1041-1047, 1990.

27. Nagai R. , Kuro-o M. , Babij P. , Periasamy M. .Identification of two types of smooth muscle myosin heavy chain isoforms by cDNA cloning and immunoblot analysis.J. Biol. Chem. 264: 9734-9737, 1989.

28. Pollard T. D. .Electron microscopy of synthetic myosin filaments: evidence for crossbridge flexibility and coploymer formation..J. Cell Biol. 67: 93-104, 1975.

29. Rovner A. S. , Thompson M. M. , Murphy R. A. .Two different heavy chains are found in smooth muscle myosin..Am. J. Physiol. Cell Physiol. 19 250: C861-C870, 1986.

30. Shohet R. V. , Conti M. A. , Kawamoto S. , Preston Y. A. , Brill D. A. , Adelstein R. S. .Cloning of the cDNA encoding the myosin heavy chain of a vertebrate cellular myosin..Proc. Natl. Acad. Sci. USA 86: 7726-7730, 1989.

31. Sinard J. H. , Rimm D. L. , Pollard T. D. .Identification of functional regions on the tail of Acanthamoebamyosin II using recombinant fusion proteins II: assembly properties of tails with $\mathrm{NH}_{2}$ - and COOH-terminal deletions..J. Cell Biol. 111: 2417-2426, 1990.

32. Sinard J. H. , Stafford W. F. , Pollard T. D. .The mechanism of assembly of Acanthamoeba myosin II minifilaments: minifilaments assemble by three successive dimerization steps..J. Cell Biol. 109: 1537-1547, 1989.

33. Sleek G. E. , Duling B. R. .Coordination of mural elements and myofilaments during arteriolar constriction..Circ. Res. 59: 620-627, 1986.

34. Sohn U. D. , Chiu T. T. , Bitar K. N. , Hillemeier C. , Behar J. , Biancani P. .Calcium requirements for acetylcholine-induced contraction of cat esophageal circular muscle cells..Am. J. Physiol. Gastrointest. Liver Physiol. 29 266: G330-G338, 1994.

35. Sparrow M. P. , Mohammad M. A. , Arner A. , Hellstrand P. , Rüegg J. C. .Myosin composition and functional properties of smooth muscle from the uterus of pregnant and non-pregnant rats..Pflügers Arch.412: 624-633, 1988.

36. VanBuren P., Harris D. E. , Alpert N. R. , Warshaw D. M. .Cardiac V1 and V3 myosins differ in their hydrolytic and mechanical activites in vitro..Circ. Res. 77: 439-444, 1995.

37. Wachsberger P. R. , Pepe F. A. .Interaction between vertebrate skeletal and uterine muscle myosins and light meromyosins..J. Cell Biol. 85: 33-41, 1980.

38. Walsh M. P. , Andrea J. E. , Allen B. G. , Clement-Chomienne O. , Collins E. M. , Morgan K. G. .Smooth muscle protein kinase C..Can. J. Physiol. Pharmacol. 72: 1392-1399, 1994. 
39. Wang Z. , Gopalakurup S. K. , Levin R. M. , Chacko S. .Expression of smooth muscle myosin isoforms in urinary bladder smooth muscle during hypertrophy and regression..Lab. Invest. 73: 244-251, 1995.

40. Yanagisawa M. , Hamada Y. , Katsuragawa Y. , Imamura M. , Mikawa T. , Masaki T. .Complete primary structure of vertebrate smooth muscle myosin heavy chain deduced from its complementary DNA sequence..J. Mol. Biol. 198: 143-157, 1987. 